\title{
Evaluation of Antioxidant, Anticholinesterase and Antityrosinase Activities of Malaysian Cinnamomum Species
}

\author{
Wan Mohd Nuzul Hakimi Wan Salleh ${ }^{1}$, Farediah Ahmad ${ }^{1}$ and Khong Heng Yen ${ }^{2}$ \\ ${ }^{1}$ Department of Chemistry, Faculty of Science, University Teknologi Malaysia (UTM), Skudai, 81310 Johor \\ Bahru, Johor, Malaysia \\ ${ }^{2}$ School of Chemistry and Environment Studies, Faculty of Applied Sciences, University Teknologi MARA
}

(UiTM) Sarawak, Jalan Meranek, 94300 Kota Samarahan, Sarawak, Malaysia

Received: November 02, 2015; Accepted: January 20, 2016; Published (web): January 31, 2016

\begin{abstract}
The extracts of the leaves and bark of five Cinnamomum species (C. altissimum, C. griffithii, C. javanicum, C. macrocarpum, and $C$. velutinum) were screened to evaluate their antioxidant, anticholinesterase, and antityrosinase activities. The bark of $C$. altissimum showed the highest phenolic content (130.1 mg GA/g), free radical scavenging by DPPH $\left(\mathrm{IC}_{50} 126.2 \mu \mathrm{g} / \mathrm{mL}\right.$ ) and ferric reducing antioxidant power (FRAP) assays (341.2 $\mathrm{mg}$ $\mathrm{AA} / \mathrm{g}$ ). All of the extracts inhibited linoleic acid peroxidation by greater than $70 \%$, with the leaves of $C$. altissimum exhibiting the highest inhibition of $87.7 \%$. The leaves of C. javanicum revealed the highest inhibition on anticholinesterase (AChE 30.8\%) and butyrylcholinesterase (BChE 46.8\%) enzymes. The leaves and bark of $C$. altissimum and C. velutinum exhibited greater than $20 \%$ tyrosinase inhibition, with the leaves of $C$. altissimum having the highest percentage of inhibition (34.6\%). These bioactivities indicate that some Cinnamomum species have therapeutic potential in medicinal research and development of new drugs candidates.
\end{abstract}

Key words: Lauraceae, Cinnamomum, antioxidant, anticholinesterase, antityrosinase

\section{INTRODUCTION}

Cinnamomum, belonging to the family Lauraceae, is a genus of trees found in continental Asia, eastern and southeastern Asia, Australia, the Pacific region, and a few species in Central and South America. In Malaysia, twenty one species have been found in tropical rain forests where they grow at various altitudes from highland slopes to lowland forests and occur in both marshy places and on welldrained soils. ${ }^{1}$ Cinnamon has been used as a spice for thousands of years. In Ayurvedic medicine, cinnamon bark has been used as an antiemetic, antidiarrheal, antiflatulent, and general stimulant. ${ }^{2}$ Systematic chemical studies with the essential oils of some of the Malaysian species have been carried out.

Correspondence to: Farediah Ahmad Tel: +607-5534137; Fax: +607-5566162

Email: farediah@kimia.fs.utm.my

Dhaka Univ. J. Pharm. Sci. 14(2): 125-132, 2015 (December)
The oils were found to contain mainly safrole, eugenol, linalool, camphor, benzylbenzoate, or cinnamaldehyde as major components. ${ }^{3-5}$ The cinnamon oil is used as flavoring ingredient in foods and drinks, as a perfumery material, and in many pharmaceutical preparations for its carminative and astringent properties. ${ }^{6}$ Besides, the cinnamon extracts have been found to be impersonating the function of insulin, while the extracts also can potentiate insulin action in isolated adipocytes and also enhanced the insulin receptor function. ${ }^{7,8}$ Hence, considering the various medicinal benefits of Cinnamomum, an effort has been made to establish the scientific validity through screening for antioxidant, anticholinesterase, and antityrosinase inhibitory activities of methanolic leaves and bark extracts of five Cinnamomum species. Table 1 shows the traditional uses of the selected Cinnamomum species. ${ }^{9}$ 
Table 1. List of five Cinnamomum species and their traditional uses.

\begin{tabular}{|c|c|c|}
\hline Botanical name & Vernacular names & Traditional uses \\
\hline C. altissimum Kosterm. & No report & The leaves, stem bark and stem wood have been used to treat wound infections. \\
\hline C. griffithii Meisn. & Babau & A decoction of the roots is given to women after childbirth and also to treat fever. \\
\hline C. javanicum Blume & Daun buluh & $\begin{array}{l}\text { The leaves are used medicinally with Kadsura scandens to treat stomachache and } \\
\text { to initiate abortion. The root decoction is drunk to treat fatigue and chest pain. }\end{array}$ \\
\hline C. macrocarpum Hook.f. & Lavanga & $\begin{array}{l}\text { The leaves are used for flavouring rice dishes. The bark is reported to be used as a } \\
\text { substitute/adulterant of the bark of C. zeylanicum which is traded in large } \\
\text { quantities as a spice as well as a raw plant drug. It is also used in Ayurveda, Folk } \\
\text { and Sidha. }\end{array}$ \\
\hline C. velutinum Ridl. & Medang teja & No report. \\
\hline
\end{tabular}

\section{MATERIALS AND METHODS}

Plant materials. Five Cinnamomum species were collected from Bau and Lundu, Sarawak and identified by Mohizar Mohamad. The voucher specimen (UiTMKS/C01-05) was deposited at the Natural Products Research \& Development Centre (NPRDC), UiTM Sarawak.

Solvents and chemicals. Antioxidant: $\beta$ carotene, linoleic acid, chloroform (HPLC grade), Tween 40, Folin-Ciocalteau reagent, gallic acid, anhydrous sodium carbonate 99\%, 1,1-diphenyl-2picrylhydrazyl (DPPH), butylated hydroxytoluene (BHT), ascorbic acid, 2,4,6-tripyridyl-s-triazine (TPTZ), and iron (III) chloride hexahydrate were purchased from Sigma-Aldrich, USA.

Anticholinesterase: L-3,4-dihydroxyphenylalanine (L-dopa), mushroom tyrosinase and kojic acid were obtained from Sigma-Aldrich, USA.

Antityrosinase: Electric eel AChE (Type-VI-S, EC 3.1.1.7), horse serum BChE (EC 3.1.1.8), acetylcholine iodide, S-butyrylthiocholine chloride, 5,5'-dithiobis (2-nitrobenzoic acid) 99\% (DTNB), and galantamine were purchased from SigmaAldrich, USA.

Plant extraction. The dried and powdered leaves and bark of the above-mentioned Cinnamomum species (about $100 \mathrm{~g}$, each) were subjected to cold extraction method by using methanol as solvent. The extracts were filtered and the solvent was removed under vacuum using a rotary evaporator (Eyela, Japan). The extracts were obtained and kept in freeze until the experimental practices. Percentage yields $(\mathrm{w} / \mathrm{w})$ of the crude extracts are given in Table 2.

\section{Antioxidant activity}

$\beta$-Carotene/linoleic acid bleaching: The $\beta$ carotene-linoleic acid bleaching assay as described previously was used with minor modifications. ${ }^{10} \mathrm{~A}$ mixture of $\beta$-carotene and linoleic acid was prepared by adding together of $0.5 \mathrm{mg} \beta$-carotene in $1 \mathrm{~mL}$ $\mathrm{CHCl}_{3}, 25 \mu \mathrm{L}$ linoleic acid and $200 \mathrm{mg}$ Tween 40. The $\mathrm{CHCl}_{3}$ was then completely evaporated under vacuum and $100 \mathrm{~mL}$ of oxygenated distilled water was subsequently added to the residue and mixed gently to form a clear yellowish emulsion. The extracts and BHT were individually dissolved in methanol $(2 \mathrm{~g} / \mathrm{L})$ and $350 \mu \mathrm{L}$ volumes of each of them were added to $2.5 \mathrm{~mL}$ of the above emulsion in test tubes and mixed thoroughly. The test tubes were incubated in a water bath at $50^{\circ} \mathrm{C}$ for $2 \mathrm{~h}$, together with a negative control (blank) contained the same volume of methanol. The absorbance values were measured at $470 \mathrm{~nm}$ on UV-vis spectrophotometer. Percentage inhibitions (I\%) of the extracts were calculated using the following equation:

$$
\mathrm{I} \%=\left[\mathrm{A}_{\beta \text {-carotene after 2h }} / \mathrm{A}_{\text {initial } \beta \text {-carotene }}\right] \times 100
$$

where $A_{\beta \text {-carotene after } 2 \mathrm{~h}}$ assay is the absorbance values of $\beta$-carotene after $2 \mathrm{~h}$ assay remaining in the 
samples and $\mathrm{A}_{\text {initial }} \beta$-carotene is the absorbance value of $\beta$-carotene at the beginning of the experiments. All tests were carried out in triplicate and percentage inhibitions were reported as means \pm SD of triplicates.

$D P P H$ radical scavenging: The free radical scavenging activity was measured by the DPPH method with minor modifications. ${ }^{10}$ Each sample of stock solution $(1 \mathrm{mg} / \mathrm{mL}$ in $\mathrm{MeOH})$ was diluted in various concentrations $(1000-7.8 \mu \mathrm{g} / \mathrm{mL})$. Then, a total of $3.8 \mathrm{~mL}$ of $50 \mu \mathrm{M}$ DPPH methanolic solution $(1 \mathrm{mg} / 50 \mathrm{~mL}$ ) was added to $0.2 \mathrm{~mL}$ of each sample solution and allowed to react at room temperature for $30 \mathrm{~min}$. The absorbance of the mixtures was measured at $517 \mathrm{~nm}$. A control was prepared without sample or standard and measured immediately at 0 min. The percentage inhibitions (I\%) of DPPH radical were calculated as follow:

$$
\mathrm{I} \%=\left[\mathrm{A}_{\text {blank }}-\mathrm{A}_{\text {sample }} / \mathrm{A}_{\text {blank }}\right] \times 100
$$

where $A_{\text {blank }}$ is the absorbance value of the control reaction (containing all reagents except the samples) and $\mathrm{A}_{\text {sample }}$ is the absorbance values of the test samples. The sample concentration providing 50\% inhibition $\left(\mathrm{IC}_{50}\right)$ was calculated by plotting inhibition percentages against concentrations of the sample. All tests were carried out in triplicate and $\mathrm{IC}_{50}$ values were reported as means \pm SD triplicates.

Total phenolic content (TPC): TPC of extracts were determined by gallic acid equivalent with minor modifications. ${ }^{10} \quad$ A sample of stock solution (1 $\mathrm{mg} / \mathrm{mL}$ in $\mathrm{MeOH}$ ) was diluted to final concentrations of $1000 \mu \mathrm{g} / \mathrm{mL}$. A $0.1 \mathrm{~mL}$ aliquot of sample was pipetted into a test tube containing 0.9 $\mathrm{mL}$ of $\mathrm{MeOH}$, then $0.05 \mathrm{~mL}$ Folin-Ciocalteu's reagent was added, and the flask was thoroughly shaken. After $3 \mathrm{~min}, 0.5 \mathrm{~mL}$ of $5 \% \mathrm{Na}_{2} \mathrm{CO}_{3}$ solution was added and the mixture was allowed to stand for $2 \mathrm{~h}$ with intermittent shaking. Then, $2.5 \mathrm{~mL}$ of $\mathrm{MeOH}$ was added and left to stand in the dark for $1 \mathrm{~h}$. The absorbance measurements were recorded at $765 \mathrm{~nm}$. The same procedure was repeated for the standard gallic acid solutions. The concentration of total phenolic contents in the extracts was expressed as mg of gallic acid equivalent per gram of sample. Tests were carried out in triplicate and the gallic acid equivalent value was reported as mean $\pm \mathrm{SD}$ of triplicate.

Ferric reducing antioxidant power (FRAP): The total reducing capacity was determined using FRAP assay. ${ }^{11}$ The stock solutions included $300 \mathrm{mM}$ acetate buffer $\mathrm{pH} 3.6,10 \mathrm{mM}$ TPTZ solution in 40 $\mathrm{mM} \mathrm{HCl}$, and $20 \mathrm{mM} \mathrm{FeCl}_{3} \cdot 6 \mathrm{H}_{2} \mathrm{O}$ solution. The fresh working solution was prepared by mixing $25 \mathrm{~mL}$ acetate buffer, $2.5 \mathrm{~mL}$ TPTZ, and $2.5 \mathrm{~mL}$ $\mathrm{FeCl}_{3} \cdot 6 \mathrm{H}_{2} \mathrm{O}$. The temperature of the solution was raised to $37{ }^{\circ} \mathrm{C}$ prior to use. The extracts $(150 \mu \mathrm{L})$ was allowed to react with $2850 \mu \mathrm{L}$ of the FRAP solution for $30 \mathrm{~min}$ in the dark condition. After incubation, the absorbance was read at $593 \mathrm{~nm}$ using a UV-Vis spectrophotometer. The results were calculated by standard curves prepared with known concentrations of ascorbic acid (AA) and were expressed as mg AA/g.

Anticholinesterase activity. $\mathrm{AChE}$ and $\mathrm{BChE}$ inhibitory activities were measured slightly modified by Ellman spectrophotometric method. ${ }^{12}$ Briefly, 140 $\mu \mathrm{L}$ sodium phosphate buffer ( $\mathrm{pH} 8.0$ ), $20 \mu \mathrm{L}$ DTNB, $20 \mu \mathrm{L}$ extracts (concentration of $1 \mathrm{mg} / \mathrm{mL}$ ), and 20 $\mu \mathrm{L} \quad \mathrm{AChE} / \mathrm{BChE}$ solution were added by a multichannel automatic pipette in a 96-well microplate and incubated for $15 \mathrm{~min}$ at $25{ }^{\circ} \mathrm{C}$. The reaction was then initiated with the addition of $10 \mu \mathrm{L}$ AChI/BuChI. The hydrolysis of AChI/BuChI chloride was monitored by the formation of yellow 5thio-2-nitrobenzoate anion from the reaction of DTNB with thiocholine, catalyzed by enzymes at 412 nm, and utilizing a 96-well microplate reader (Epoch Micro-Volume Spectrophotometer). Galantamine was used as a reference. The percentage inhibition (I\%) of AChE/BChE was determined by comparing the rates of reaction of samples relative to the blank sample (EtOH in phosphate buffer $\mathrm{pH}$ 8) using the following formula:

$$
\mathrm{I} \%=[\mathrm{E}-\mathrm{S} / \mathrm{E}] \times 100
$$

where $\mathrm{E}$ is the activity of enzyme without test sample and $S$ is the activity of enzyme with test sample. Analyses were expressed as mean $\pm \mathrm{SD}$ of triplicates. 
Antityrosinase activity. Tyrosinase inhibition assay was performed according to the previous method with slight modifications. ${ }^{13}$ Briefly, the extracts and kojic acid were dissolved in DMSO prepared in the amount of $1 \mathrm{mg} / \mathrm{mL}$. The extracts (40 $\mu \mathrm{L}$ ) dissolved in DMSO with $80 \mu \mathrm{L}$ phosphate buffer (pH 6.8), $40 \mu \mathrm{L}$ tyrosinase enzyme, and $40 \mu \mathrm{L}$ L-DOPA was placed in each well. Each sample was accompanied by a blank that contained all the components except L-DOPA. Kojic acid was used as a reference standard inhibitor for comparison. The reaction was carried out using a 96-well microplate and a microplate reader (Epoch Micro-Volume Spectrophotometer) were used to measure the absorbance at $475 \mathrm{~nm}$. The percentage inhibition (I\%) was calculated as follows:

$$
\mathrm{I} \%=\left[\mathrm{A}_{\text {control }}-\mathrm{A}_{\text {sample }} / \mathrm{A}_{\text {control }}\right] \times 100
$$

where, $\mathrm{A}_{\text {control }}$ is the absorbance of the control reaction and $A_{\text {sample }}$ is the absorbance of the extracts/reference. Analyses were expressed as mean \pm SD of triplicates.

Statistical analysis. Data obtained from biological activities were expressed as means $\pm \mathrm{SD}$ and were compared using student's t-test. The statistical analyses were carried out employing one way ANOVA $(p<0.05)$. A statistical package (SPSS version 11.0) was used for the data analysis.

\section{RESULTS AND DISCUSSION}

The antioxidant activity of the leaves and bark extracts was evaluated by four tests: DPPH radical scavenging, $\beta$-carotene-linoleic acid, total phenolic content, and FRAP assays. The results for antioxidant activities are presented in table 2 .

Table 2. Percentage yield and antioxidant activities of five Cinnamomum species.

\begin{tabular}{lccccc}
\hline Sample & Yield $(\%)$ & $\beta$-carotene $(\mathrm{I} \%)$ & $\begin{array}{c}\text { DPPH IC } 50 \\
(\mu \mathrm{g} / \mathrm{mL})\end{array}$ & $\begin{array}{c}\text { TPC } \\
(\mathrm{mg} \mathrm{GA} / \mathrm{g})\end{array}$ & $\begin{array}{c}\text { FRAP } \\
(\mathrm{mg} \text { AA/g) }\end{array}$ \\
\hline CAL & 2.13 & $87.7 \pm 0.4$ & 242.4 & $110.6 \pm 0.4$ & $340.6 \pm 0.8$ \\
CAB & 2.22 & $85.2 \pm 0.3$ & 126.2 & $130.1 \pm 0.2$ & $341.2 \pm 0.4$ \\
CGL & 2.96 & $82.0 \pm 0.2$ & 226.4 & $69.6 \pm 0.2$ & $149.2 \pm 0.4$ \\
CGB & 2.45 & $81.5 \pm 0.3$ & 197.4 & $87.2 \pm 0.3$ & $95.2 \pm 0.2$ \\
CJL & 2.80 & $84.0 \pm 0.3$ & 223.5 & $76.8 \pm 0.3$ & $207.6 \pm 0.3$ \\
CJB & 2.68 & $78.6 \pm 0.2$ & 197.4 & $72.0 \pm 0.3$ & $125.0 \pm 0.2$ \\
CML & 2.12 & $70.8 \pm 0.3$ & 200.6 & $45.8 \pm 0.2$ & $109.8 \pm 0.5$ \\
CMB & 2.24 & $70.3 \pm 0.4$ & 159.4 & $54.4 \pm 0.2$ & $240.8 \pm 1.3$ \\
CVL & 1.92 & $74.2 \pm 0.2$ & 196.6 & $79.6 \pm 0.2$ & $176.2 \pm 0.2$ \\
CVB & 1.96 & $72.0 \pm 0.3$ & 178.5 & $72.0 \pm 0.3$ & $243.0 \pm 0.4$ \\
\hline BHT & & 125.5 & 32.4 & ND & ND \\
\hline
\end{tabular}

Data represent mean $\pm \mathrm{SD}$ of three independent experiments; ND - not determined; CAL - C. altissimum leaf; CAB - C. altissimum bark; CGL - C. griffithii leaf; CGB - C. griffithii bark; CJL - C. javanicum leaf; CJB - $C$. javanicum bark; CML - C. macrocarpum leaf; CMB - C. macrocarpum bark; CVL - C. velutinum leaf; CVB C. velutinum bark.

In DPPH assays, the test intends to measure the hydrogen atom or electron donor capacity of the extracts to the stable radical DPPH formed in solution. It measures the capacity of the extract to scavenge free radicals in solution. ${ }^{14}$ The bark extract of $C$. altissimum and C. macrocarpum showed the lowest $\mathrm{IC}_{50}$ value in DPPH which exhibited strong antioxidant activity, with $\mathrm{IC}_{50}$ value of 126.2 and $159.4 \mu \mathrm{g} / \mathrm{mL}$, respectively. However, this value was four times lower than those found with the 
antioxidant standard, BHT with $\mathrm{IC}_{50} 32.4 \mu \mathrm{g} / \mathrm{mL}$. The other extracts that showed $\mathrm{IC}_{50}$ value $<200 \mu \mathrm{g} / \mathrm{mL}$, were C. griffithii (bark $197.4 \mu \mathrm{g} / \mathrm{mL}$ ), C. javanicum (leaves $197.4 \mu \mathrm{g} / \mathrm{mL}$ ) and C. velutinum (leaves 196.6 $\mu \mathrm{g} / \mathrm{mL}$; bark $178.5 \mu \mathrm{g} / \mathrm{mL}$ ). In $\beta$-carotene-linoleic acid, the activity measured as the inhibition of oxidation of linoleic acid can simulate the oxidation of the membrane lipid components and also measures the capacity of inhibition of conjugated diene hydroperoxide arising from the linoleic acid oxidation. This test measures the antioxidant activity toward linoleic acid relatively to $\beta$-carotene. ${ }^{14}$ In $\beta$ carotene-linoleic acid, the results showed that the Cinnamomum extracts were in the range of 70.3-87.7\%. Moderate inhibitory activity was exhibited by the leaves and bark extracts of $C$. altissimum extracts which revealed $87.7 \%$ and bark $85.2 \%$, respectively, followed by extracts of $C$. griffithii (leaves 82.0\%; bark 81.5), and C. javanicum (leaves $84.0 \%$; bark $78.6 \%$ ). In phenolic content assay, the phenolic compounds have been shown to be responsible for the antioxidant activity of plant materials and hence many of the natural polyphenols possess therapeutic potential. ${ }^{15}$ The total phenolic content (TPC) values were quantified based on the linear equation obtained from gallic acid standard calibration curve $\left(\mathrm{y}=0.0021 x-0.0223 ; r^{2}=0.9928\right)$. Thus, TPC values were expressed as gallic acid equivalent (mg GAE/g extracts). From the table, leaves and bark extract of $C$. altissimum had the highest content of phenolic which gave $110.6 \pm 0.4$ and $130.1 \pm 0.2 \mathrm{mg} \mathrm{GA} / \mathrm{g}$ extract, respectively. FRAP assay is presented as an accurate method for assessing antioxidant power. Ferric to ferrous ion reduction at low $\mathrm{pH}$ causes a colored ferroustripyridyltriazine complex to form. FRAP values are obtained by comparing the absorbance change at $593 \mathrm{~nm}$ in test reaction mixtures with that containing ferrous ions in known concentration. In FRAP assay, the highest values showed by the bark extracts of $C$. altissimum (341.2 mg AA/g). FRAP assay is widely used in the evaluation of the antioxidant component in dietary polyphenols due to inexpensive, reagents are simple to prepare, results are highly reproducible, and the procedure is straightforward and speedy. ${ }^{16}$ Previous work carried out on Cinnamomum species had obtained higher antioxidant activity in plant extracts such as $C$. camphora, C. cassia, C. tamala, C. zeylanicum, $C$. osmophloeum, $C$. triplinerve, $C$. iners, and $C$. verum. ${ }^{17-20}$ This suggests that flavonoid glycosides, proanthocyanidins, cinnamic acid, coumarin, and lignans known to have antioxidant activity may be responsible for the activity. ${ }^{21}$

According to the results at table 3 we obtained, the leaves extract from $C$. javanicum (AChE 30.8\%; BChE $46.8 \%$ ) and C. velutinum (AChE $30.5 \%$; $\mathrm{BChE}$ 46.5\%) exerted the highest $\mathrm{AChE}$ and $\mathrm{BChE}$ inhibition. However the results of the extracts for $\mathrm{AChE}$ was three times lower than galantamine which gave $95.9 \%$, while for $\mathrm{BChE}$ was two times lower than that standard which gave $88.7 \%$. In addition, the leaves extract of C. macrocerpum (AChE 29.5\%; BChE 45.7\%) and C. griffithii (AChE 27.1\%; BChE $43.8 \%$ ) were also found to have significant inhibition. However, no activity were recorded on $\mathrm{AChE}$ from the bark of $C$. griffithii and C. javanicum as well as leaves and bark of $C$. altissimum. Inhibition of AChE, the key enzyme in the breakdown of acetylcholine, is considered as one of the treatment strategies against several neurological disorders such as Alzheimer disease. ${ }^{22}$ Anticholinesterase inhibitory activity of the extracts was tested against acetylcholinesterase and butyrylcholinesterase at different concentrations. Our literature survey revealed the presence of few report on cholinesterase inhibitory activity of Cinnamomum species. Kumar et al. ${ }^{23}$ reported that aqueous extract of C. zeylanicum gave inhibitory activity of $46.8 \%$ for $\mathrm{AChE}$ and $51.7 \%$ for BChE enzyme. The ethanol extract showed percentage inhibition of $40.8 \%$ and $51.5 \%$ for $\mathrm{AChE}$ and $\mathrm{BChE}$, respectively. Cinnamomum extract has been found to have an inhibitory effect on tau aggregation related to AD. The extract can also promote complete disassembly of recombinant tau filaments and cause substantial alteration of the morphology of paired-helical filaments isolated from AD brain. Recently, orally administered Cinnamomum extract has been found to reduce $\beta$-amyloid oligomerization and correct cognitive impairment in $\mathrm{AD}$ animal models. ${ }^{24}$ 
Table 3. Anticholinesterase and antityrosinase activities of five Cinnamomum species.

\begin{tabular}{lccc}
\hline Samples & \multicolumn{2}{c}{ Anticholinesterase (\%) } & Antityrosinase (\%) \\
\cline { 2 - 3 } & AChE & BChE & $34.6 \pm 0.3$ \\
\hline CAL & NA & $19.9 \pm 0.2$ & $32.2 \pm 0.3$ \\
CAB & NA & $12.8 \pm 0.2$ & NA \\
CGL & $27.1 \pm 0.2$ & $43.8 \pm 0.3$ & NA \\
CGB & NA & $18.1 \pm 0.2$ & $18.4 \pm 0.2$ \\
CJL & $30.8 \pm 0.2$ & $46.8 \pm 0.3$ & $6.4 \pm 0.1$ \\
CJB & NA & $20.6 \pm 0.2$ & $21.3 \pm 0.2$ \\
CML & $29.5 \pm 0.3$ & $45.7 \pm 0.2$ & $28.2 \pm 0.3$ \\
CMB & $6.4 \pm 0.2$ & $28.0 \pm 0.1$ & $13.9 \pm 0.2$ \\
CVL & $30.5 \pm 0.2$ & $46.5 \pm 0.3$ & $11.4 \pm 0.3$ \\
CVB & NA & $22.3 \pm 0.2$ & ND \\
\hline Galantamine & $95.9 \pm 0.2$ & $88.7 \pm 0.2$ & $81.8 \pm 0.5$ \\
\hline Kojic acid & ND & ND & \\
\hline
\end{tabular}

Data represent mean \pm SD of three independent experiments; NA - not active; ND - not determined; CAL - C. altissimum leaf; CAB - $C$. altissimum bark; CGL - C. griffithii leaf; CGB - C. griffithii bark; CJL - C. javanicum leaf; CJB - C. javanicum bark; CML - C. macrocarpum leaf; CMB - C. macrocarpum bark; CVL - C. velutinum leaf; CVB - C. velutinum bark

Table 3 showed that leaves and bark extracts of C. altissimum revealed the highest antityrosinase activity with $34.6 \%$ and $32.2 \%$, respectively. However it is three times lower than that of kojic acid, $81.8 \%$ inhibition. Meanwhile, the extracts that showed inhibition more than $20 \%$ were leaves (21.3\%) and bark (28.2\%) of C. macrocarpum. Tyrosinase, also known as monophenol monooxygenase, catechol oxidase or diphenol oxidase, is a coppercontaining enzyme present in plant, animal, and fungal species that catalyzes the production of melanin and other pigments from tyrosine by oxidation. Tyrosinase inhibitors are used in treatment of various skin diseases such as hyperpigmentation and melasma. Many inhibitors of this enzyme have been reported to contain phenolic structure such as kojic acid and arbutin. ${ }^{25}$ Antityrosinase activity of the extracts was tested using L-dopa as a substrate. A few studies on Cinnamomum species have been tested on their extracts for antityrosinase activity. Methanolic extracts of $C$. zeylanicum leaves showed inhibition $72.7 \%$ at $100 \mu \mathrm{g} / \mathrm{mL}$, while the methanol extract of C. cassia twigs was found to possess tyrosinase inhibitory activity with percentage inhibition $>85 \%$ at the same concentration. ${ }^{26,27}$ The present investigation was delineated to evaluate the preliminary screening of enzyme inhibitory activities of the plant extracts. The expected bioactive components could be flavonoids, aromatic acids, polyphenols, or aromatic aldehydes as these compounds consist of hydrophobic parts which could probably act as competitive inhibitors in the synthesis of melanin. ${ }^{28}$ Previous studies showed that proanthocyanidins have been isolated from C. zeylanicum and C. cassia. ${ }^{29,30}$ Meanwhile, little is known of the lightening effect of proanthocyanidin on UV-induced pigmentation of the skin but they showed that grape seed extract, rich in proanthocyanidins, inhibited the activity of mushroom tyrosinase and inhibited melanogenesis without inhibiting the growth of cultured B16 mouse melanoma cells. ${ }^{31}$ 'Quebracho', an extract rich in proanthocyanidins, isolated from the heartwood of Schinopsis lorentzii with $70 \%$ aqueous acetone, showed $47 \%$ tyrosinase inhibition. ${ }^{32}$

\section{CONCLUSIONS}

The present findings support the use of the five Cinnamomum species in traditional medicine and indicate their potential in providing biologically active compounds. Since the activities exhibited by these species were from leaves and stems and not the bark that is generally used, substitution of the bark with these plant parts will impact on conservation. 
This will add more value on the sustainable uses of these species, especially in areas where they are protected due to overexploitation. The data will also add to the knowledge base needed to advance the local management of diseases.

\section{ACKNOWLEDGMENTS}

The authors thank the Ministry of Science, Technology and Innovation Malaysia for financial support under research vote QJ130000.2526.03H93 (GUP) and the Department of Chemistry, Faculty of Science, Universiti Teknologi Malaysia (UTM) for research facilities.

\section{REFERENCES}

1. Jantan, I., Yalvema, M.F., Ahmad, N.W. and Jamal, J.A. 2005. Insecticidal activities of the leaf oils of eight Cinnamomum species against Aedes aegypti and Aedes albopictus. Pharm. Biol. 43, 526-532.

2. Hsieh, P.C. 2000. Antimicrobial effect of cinnamon extract Taiwanese. J. Agric. Food Chem. 38, 184-193.

3. Jantan, I. and Goh, S.H. 1992. Essential oils of Cinnamomum species from Peninsular Malaysia. J. Essent. Oil Res. 4, 161-171.

4. Jantan, I., Noorsiha, A., Hiong, A.E. and Ahmad, A.S. 2002. Chemical composition of the essential oils of Cinnamomum cordatum Kosterm. Flav. Frag. J. 17, 212-214.

5. Jantan, I., Ling, Y.E., Romli, S. and Ayop, N. 2003. A comparative study of the constituents of the essential oils of three Cinnamomum species from Malaysia. J. Essent. Oil Res. 15, 387-391.

6. Lawrence, B.M. 1967. A review of some of the commercial aspects of Cinnamon. Perf. Essent. Oil Res. 58, 236-241.

7. Broadhurst, C.L., Polansky, M.M. and Anderson, R.A. 2000. Insulin-like biological activity of culinary and medicinal plant aqueous extracts in vitro. J. Agric. Food Chem. 48, 849-852.

8. Jarvill-taylor, K.J., Anderson, R.A. and Graves, D.J. 2001. A hydroxychalcone derived from cinnamon functions as a mimetic for insulin in 3T3-L1 adipocytes. J. Am. Coll. Nutr. 20, 327-336

9. Soh, W.K. 2011. Taxonomic revision of Cinnamomum (Lauraceae) in Borneo. Blumea 56, 241-264.

10. Tepe, B., Daferera, D., Sokmen, A., Sokmen, M. and Polissiou, M. 2005. Antimicrobial and antioxidant activities of the essential oil and various extracts of Salvia tomentosa Miller (Lamiaceae). Food Chem. 90, 333-340.
11. Rice-Evans, C., Miller, N.J. and Paganga, G. 1996. Structureantioxidant activity relationships of flavonoids and phenolic acids. Free Radic. Biol. Med. 20, 933-956.

12. Luximon-Ramma, A., Bahorun, T., Soobrattee, M.A. and Aruoma, I. 2005. Antioxidant activities of phenolic, proanthocyanidin and flavonoid components in extracts of Acacia fistula. J. Agric. Food Chem. 50, 5042-5047.

13. Argoti, J.C., Salido, S., Linares-Palomino, P.J., Ramírez, B., Insuasty, B. and Altarejos, J. 2011. Antioxidant activity and free radical scavenging capacity of a selection of wildgrowing Colombian plants. J. Sci. Food Agric. 91, 2399 2406.

14. Anis, Z., Sulaiman, O., Hashim, R., Mehdi, S.H. and Ghalib, R.M. 2012. Radical scavenging activity, total phenol content and antifungal activity of Cinnamomum iners wood. Iranica J. Energy Environ. 3, 74-78.

15. Yang, C.H., Li, R.X. and Chuang, L.Y. 2012. Antioxidant activity of various parts of Cinnamomum cassia extracted with different extraction methods. Molecules 17, 7294-7304.

16. Wu, C.L., Chang, H.T., Hsui, Y.R., Hsu, Y.W., Liu, J.Y., Wang, S.Y. and Chang, S.T. 2013. Antioxidant-enriched leaf water extracts of Cinnamomum osmophloeum from eleven provenances and their bioactive flavonoid glycosides. Bio. Resources, 8, 571-580.

17. Jayaprakasha, G.K., Ohnishi-Kameyama, M., Ono, H., Yoshida, M. and Jaganmohan-Rao, L. 2006. Phenolic constituents in the fruits of Cinnamomum zeylanicum and their antioxidant activity. J. Agric. Food Chem. 54, 1672 1679 .

18. Mukherjee, P.K., Kumar, V., Mal, M. and Houghton, P.J. 2007. Acetylcholinesterase inhibitorsfrom plants. Phytomedicine 14, 289-300.

19. Kumar, S., Brijeshlata and Dixit, S. 2012. Screening of traditional indian spices for inhibitory activity of acetylcholinesterase and butyrylcholinesterase enzymes. Int. J. Pharma. Bio. Sci. 3, 59-65.

20. Frydman-Marom, A., Levin, A., Farfara, D., Benromano, T., Scherzer-Attali, R., Peled, S., Vassar, R., Segal, D., Gazit, E., Frenkel, D. and Ovadia, M. 2011. Orally administered cinnamon extract reduces $\beta$-amyloid oligomerization and corrects cognitive impairment in AD animal models. PLoS One doi: 10.1371/journal.pone. 0016564

21. Nerya, O., Musa, R., Khatib, S., Tamir, S. and Vaya, J. 2004. Chalcones as potent tyrosinase inhibitors: the effect of hydroxyl positions and numbers. Phytochemistry 65, 13891395. 
22. Ngoc, T.M., Lee, I., Ha-do, T., Kim, H., Min, B. and Bae, K. 2009. Tyrosinase inhibitory constituents from the twigs of Cinnamomum cassia. J. Nat. Prod. 72, 1205-1208.

23. Nair, S.S., Kavrekar, V., Mishra, A., Nithyakala, C.M. and Somashekharaiah, B.V. 2013. Investigation of inhibitory activity of selected plant extracts on tyrosinase extracted from Solanum tuberosum. Adv. Biotech. 12, 15-17.

24. Blois, M.S. 2001. Antioxidant activity of grape seed extracts on peroxidation models in vitro. J. Agric. Food Chem. 55, 1018-1022.

25. Taher, M., Majid, F.A.A. and Sarmidi, M.R. 2006. A proanthocyanidin from Cinnamomum zeylanicum stimulates phosphorylation of insulin receptor in 3t3-11 adipocytes. $J$ Tek. 44, 53-68.

26. Killday, K.B., Davey, M.H., Glinski, J.A., Duan, P., Veluri, R., Proni, G., Daugherty, F.J. and Tempesta, M.S. 2011. Bioactive A-type proanthocyanidins from Cinnamomum cassia. J. Nat. Prod. 74, 1833-1841.

27. Yamakoshi, J., Otsuka, F., Sano, A., Tokutake, S., Saito, M., Kikuchi, M. and Kubota, Y. 2006. Lightening effect on ultraviolet-induced pigmentation of guinea pig skin by oral administration of a proanthocyanidin-rich extract from grape seeds. Pigment Cell Melanoma Res. 16, 629-638.

28. Takagi, K. and Mitsunaga, T. 2003. Tyrosinase inhibitory activity of proanthocyanidins from woody plants. J. Wood Sci. 49, 461-465
29. Salleh, W.M.N.H.W., Ahmad, F., Yen, K.H. and Sirat, H.M. 2012. Chemical compositions, antioxidant and antimicrobial activity of the essential oils of Piper officinarum (Piperaceae). Nat. Prod. Commun. 7, 1659-1662

30. Benzie, I.F. and Strain, J.J. 1996. The ferric reducing ability of plasma (FRAP) as a measure of antioxidant power: The FRAP assay. Anal. Biochem. 239, 70-76.

31. Ellman, G.L., Courtney, K.D., Andres, V. and Feather-Stone, R.M. 1961. A new and rapid colorimetric determination of acetylcholinesterase activity. Biochem. Pharmacol. 7, 88-95.

32. Salleh, W.M.N.H.W., Hashim, N.A., Ahmad, F. and Yen, K.H. 2014. Anticholinesterase and antityrosinase activities of ten Piper species from Malaysia. Adv. Pharm. Bull. 4, 527-531. 